\title{
The Right to Privacy of Prospective Jurors During Voir Dire
}

Past discussions on the proper scope of voir dire inquiry have concerned themselves almost exclusively with the need to protect the right of the parties to an impartial jury. ${ }^{1}$ This focus on the parties' rights has occurred to the virtual exclusion of any discussion concerning the prospective jurors' privacy interests. ${ }^{2}$ These interests may be infringed if the voir dire questioning results in the disclosure of personal information that the prospective jurors would have preferred to have kept private. In such a situation the parties' interest in having an impartial jury may conflict with the prospective jurors' interest in avoiding disclosure of personal matters, calling for a determination as to which interest should prevail. ${ }^{3}$

The potential conflict between these two interests may be illustrated by the following hypothetical. Suppose that an alderman from a small community is asked to appear as a prospective juror in a case where a former psychiatric patient alleges that he has suffered ten thousand dollars in damages due to medication improperly prescribed and administered by the psychiatric institution's staff. The alderunan, a highly respected figure in the community who is frequently called upon for advice, had serious personal problems soine years ago and sought psychiatric care. He left the small community under the pretense of a vacation, in order to avoid the real reason becoming public, and received treatment at a psychiatric institution for a short period. Suppose further that as part of the voir dire, the defendant's attorney wants to ask each prospective juror whether he or she has ever been a patient at

1. See, e.g., Babcock, Voir Dire: Preserving "Its Wonderful Power", 27 STAN. L. Rev. 545 (1975); Note, Voir Dire: Establishing Minimum Standards to Facilitate the Exercise of Peremptory Challenges, 27 STAN. L. Rev. 1493 (1975); Note, Community Hostility and the Right ro an Impartlal Jury, 60 CoLum. L. Rev. 349 (1960); Note, Selection of Jurors by Voir Dire Examination and Challenge, 58 Yale L.J. 638 (1949). See also Ham v. South Carolina, 409 U.S. 524 (1973); Swain v. Alabama, 380 U.S. 202 (1965); Aldridge v. United States, 283 U.S. 308 (1931).

2. But see United States v. Barnes, 604 F.2d 121, 140, 143 (2d Cir. 1979) (recognizing the privacy of prospective jurors as a proper consideration in determining whether a proposed voir dire question should be permitted). For an analysis of the Barnes decision and its implications as to the existence of a right to privacy for prospective jurors, sce Note, The Defendant's Right to an Impartial Jury and the Rights of Prospective Jurors, 48 U. CIN. L. REV. 985 (1979), and Note, Voir Dire Limitations As a Means of Protecting Juror's Safety and Privacy, 93 HARV. L. Rev. 782 (1980).

3. Probing voir dire questioning may also conflict with first amendment religious and associational rights, see generally Craig, Erickson, Friesen \& Maxwell, Voir Dire: Crillcism and Comment, 47 DEN. L.J. 465 (1970), as well as other constitutional safeguards. This Comment, however, is limited to an examination of the privacy right conflict. 
a psychiatric hospital. Permitting the question to be asked threatens the alderman's privacy, whether he answers it or not. To admit in the presence of the other venire persons that he has been a psychiatric patient would almost certainly have a dainaing effect on his reputation and standing in the community. To refuse to answer would not only subject him to conteinpt charges ${ }^{4}$ but could still dannage his reputation and standing, because his refusal to answer inay lead persons present at the venire to conclude that he is trying to conceal having received psychiatric treatment. ${ }^{5}$ On the other hand, not permitting the question to be asked inay impair the ability of the defendant's attorney to weed out biased persons and thereby infringe his client's right to an impartial jury. ${ }^{6}$

Recognizing the potential for such a conflict, this Comment suggests a resolution based on an analysis of the competing interests. Part I argues that a constitutional right to privacy exists for prospective jurors. Part II examines the frequently conflicting right of the parties to have their case decided by an impartial jury. Based on this analysis, Part III then fornulates a test by which the two interests can be weighed and a determination made as to which interest should prevail when considering whether to permit a particular question to be asked during voir dire.

I

The Prospective Juror's Right to Privacy

The question of whether an individual has a constitutionally protected right to avoid disclosing private inatters was first addressed by the Supreine Court in Whalen v. Roe. ${ }^{7}$ Whalen involved a New York

4. The decision of whether to impose the sanction of a contempt charge for refusing to answer is discretionary with the judge. See 18 U.S.C. $\$ 401$ (Supp. III 1979). It may be that the prospective juror has a valid basis for not wanting to answer a particular question, and rather than hold the juror in contempt, the judge may call him aside to justify the reason for not answering. Likewise, it may be that refusal to answer a question deemed "necessary" to ensuring impartiality will result in a challenge for cause and after the jury is selected the prospective juror who refused to answer will be allowed to justify his actions to the judge. If the judge finds no justification, a contempt charge nay be imposed if the judge finds such a sanction warranted under the circumstances.

5. A prospective juror in such a situation inay simply lie if the privacy interest is strong enough. This might not be the case, however, where the prospective juror suspects that the attorney somehow already knows the answer to the question and would catcl him in a lie or where the atınosphere of the moment and the fear of the courtroom and potential sanctions influence the individual to tell the truth. The real question is whether a prospective juror should even be faced with the dilemma.

6. The same problem would be posed in a case involving illegal sex acts in which the prospective juror is asked about his sexual preference, or a case involving a drunken driver cliarged with negligent manslaughter, where the prospective jurors are questioned concerning their drinking habits and any past problems associated with drinking.

7. 429 U.S. 589 (1977). 
statute that required physicians to identify patients obtaining prescription drugs within the statute's "Schedule II" category-a class of drugs having a potential for abuse as well as a recognized medical use-so that names and addresses of the prescription drug patients could be recorded in a central computer file mamtamed by the state's Departinent of Health. The patients who regularly received prescriptions for Schedule II drugs and the doctors who prescribed thein challenged the constitutionality of the statute, arguing that it invaded a "constitutionally protected 'zone of privacy" "because the ready availability of the drug-use information created a genuine concern that it might become publicly known, thereby adversely affecting the patients' reputations. ${ }^{8}$ Although the Court rejected plaintiffs' argunent and held that there was no constitutional violation, ${ }^{9}$ it nevertheless recognized that an individual has a constitutionally protected right to nondisclosure of certain personal matters. ${ }^{10}$ The Court implied that if unwarranted disclosures were not prevented, there might very well be a constitutional violation. ${ }^{11}$

The privacy right to nondisclosure introduced in Whalen was further developed in Nixon v. Administrator of General Services. ${ }^{12}$ That case addressed the constitutionality of the Presidential Recordings and Materials Preservation Act, which provided that the Administrator of General Services take custody of former President Nixon's papers and tape recordings and promulgate regulations for public access to such materials, subject to screening of the materials by government archivists so that any private papers could be returned to Nixon. ${ }^{13}$ The Court began its analysis of Nixon's claim that the Act violated his right to privacy by noting that under Whalen, there existed a constitutionally

8. Id. at 598-600.

9. Id. at 600-04. The Court apparently rejected the argument because there was no reason for assuming that the security provisions of the statute would be improperly administered and there was no other genuine risk of public disclosure. Also, the Court could not distinguish the disclosure required by this regulation of the administration of drugs from the nonpublic disclosures required in other facets of lealth care. Id.

10. Id. at 598-600. The other privacy strand explicitly recognized by the Court was independence in making certain personal decisions-e.g., marriage, procreation, contraception. Id. Therc may be other privacy strands that are also partially undeveloped. See id. at $599 \&$ n.24. This privacy protection is founded on the fourteenth amendment's liberty right. $I d$. at 598 n.23.

11. Id. at 605-06.

12. 433 U.S. 425 (1977).

13. Presidential Recordings and Materials Preservation Act, Pub. L. No 93-526, 88 Stat. 1695 (1974).

Balancing the public imterest in preserving the materials touching Nixon's performance of his official duties against the invasion of his privacy that screening by the archivists necessarily entails, the district court concluded that the Act was not unreasonable and that the processing contemplated by the Act represented "the least intrusive manner in which to provide an adequate level of promotion of government interests of overriding importance." Nixon v. Administrator of General Services, 408 F. Supp. 321, 367 (D.D.C. 1976), affd, 433 U.S. 425 (1977). 
based privacy interest in avoiding public disclosure of personal matters. ${ }^{14}$ It refined the Whalen definition of the privacy right by adopting a "legitimate expectation of privacy" standard for determining whether the privacy interest attached. ${ }^{15}$ Applying this standard to Nixon's privacy claim, the Court acknowledged that although he was a public figure, past practices as to what materials a president has personal control over gave rise to a legitimate expectation of privacy in certain information. ${ }^{16}$ The Court then reviewed the Act, its intended purpose, its intrusive features, and the methods it employed to accomplish its ends, and weighed them against the damage and embarrassment disclosure was likely to cause Nixon. It concluded that the public's interest in having the information screened by the archivists outweighed any existing privacy interest that Nixon might have in the material. ${ }^{17}$

Whalen and Nixon thus establish that an individual has a constitutional right to privacy that protects him from the compelled disclosure of personal inatters with respect to which he has a reasonable expectation of privacy. ${ }^{18}$ Therefore, unless by becoming prospective jurors people lose their reasonable expectations of privacy or unless there are good reasons for making an exception to the constitutional protection normally accorded those expectations, prospective jurors should have a constitutional right to privacy protecting them from disclosure of personal information during voir dire.

People should not, in fact, lose their expectations of privacy by

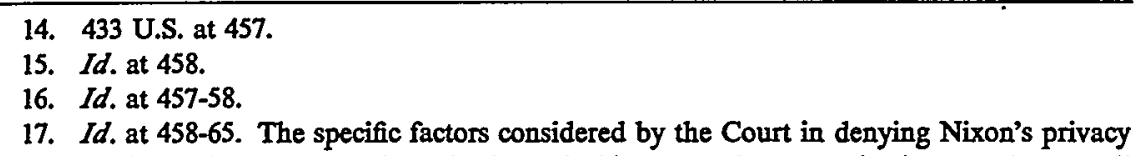
claim were his legitimate expectation of privacy in his personal communications—only a sinall portion of the inaterials covered by the Act, the virtual impossibility of segregating the sinall quantity of private materials without comprehensive screening, the limited intrusion of the screening process, the important public interest in preserving the inaterials, the unblemished record of the archivists for discretion, and the likelihood that regulations to be promulgated by the Administrator would further inoot Nixon's fears that his materials wonld be reviewed by "a lost of persons." Id. at 465.

18. Lower courts have readily accepted this constitutional right to confidentiality. See, e.g., Fadjo v. Coon, 633 F.2d 1172 (5th Cir. 1981) (plaintiff stated a valid claim in alleging a constitutionally protected right to privacy in not disclosing certain private information); General Motors Corp. v. Director of Nat'l Inst. for Occupational Safety \& Health, 636 F.2d 163 (6th Cir. 1980) (enforcement of a subpoena for employee medical records did not violate employee's privacy interest since the district court could imclude security provisions to ensure protection of information); United Steelworkers v. Marshall, 647 F.2d 1189 (D.C. Cir. 1980) (employee's constitutional right to privacy not violated by OSHA's unrestricted access to employer's health records); Schachter v. Whalen, 581 F.2d 35 (2d Cir. 1978) (subpoenas for medical records of patients being treated with laetrile did not violate the patients' right to privacy in light of the countervailing interest and the substantial procedures available to protect public disclosure of patients' names); E.I. du Pont de Nemours \& Co. v. Finklea, 442 F. Supp. 821 (S.D.W. Va. 1977) (although inedical records of cmployees protected by constitutional right to privacy, disclosure of records would not abridge privacy where there was no showing that information would be used improperly). 
becoming prospective jurors. A person may, of course, lose his expectation of privacy with respect to certain matters by taking an action that opens those matters to public scrutiny. ${ }^{19}$ Nothing about becoming a prospective juror, however, should have that effect: prospective jurors do not seek out the public forum; ${ }^{20}$ they are summoned, often unwillingly, to fulfill a public duty im the justice system. ${ }^{21}$ Prospective jurors should therefore have the saine reasonable expectations of privacy that they had as ordinary citizens. ${ }^{22}$

There are, in addition, good reasons wliy these privacy expectations of prospective jurors should be constitutionally protected. Because the prospective jurors have already made a public sacrifice, it would be a harsh imjustice to strip them of the constitutional right to privacy. Furthermore, if the risks of personal lrumiliation, damage to reputation, and public embarrassment resulting from having to answer

19. See 433 U.S. at 459: "And, of course, appellant cannot assert any privacy claim as to the documents and tape recordings that he has already disclosed to the public." In support of this statement, the Court cited Katz v. United States, 389 U.S. 347, 351 (1967). In Katz, the defendant was convicted of transmitting wagering information by telephone. At trial, the government introduced evidence of the defendant's telephone conversations, overheard by FBI agents who had attached an electronic listening and recording device to the outside of the public telephone booth from which he had placed his calls. The Supreme Court held that the evidence could not be introduced because the individual has a constitutionally protected reasonable expectation of privacy when he uses a public phone booth. In the portion of the opinion cited in Nixon, the Court stated: "What a person knowingly exposes to the public . . . is not a subject of Fourth Amendment protection. But what he seeks to preserve as private . . . may be constitutionally protected." 389 U.S. at $351-52$ (citations omitted). Reading Katz as requiring the individual to behave in a manner consistent with preserving privacy rather than requiring one to take affirmativc steps to demonstrate an intent to preserve privacy seems more consonant with fourth amendenent privacy concerns. The evaluation of measures taken to preserve privacy is an element appearing in a number of decisions following Katz as a factor in determining whether an individual exhibited a reasonable expectation of privacy. See United States v. Chadwick, 433 U.S. 1, 11 (1977) ("By placing personal effects inside a double-locked footlocker, respondents nuanifested an expectation that the contents would remain free fron public examination."); United States v. Wright, 449 F.2d 1355, 1364 (D.C. Cir. 1971), cert. denied, 405 U.S. 947 (1972) (leaving garage door ajar nine inches not a measure "calculated" to preserve interior from visual search); United States v. Haden, 397 F.2d 460, 465 (7th Cir. 1968), cert. denied, 396 U.S. 1027 (1970) ("One who intends a conversation or transaction to be private and takes reasonable steps to keep it private is protected fron governmental intrusion . . . ."); Note, Tracking Katz: Beepers, Privacy, and the Fourth Amendment, 86 YALE L.J. 1461, 1480-84 (1977).

20. Nixon's public figure status was considered as a factor in deciding that the Act did not unconstitutionally infringe his privacy interests. 433 U.S. at 465 . Despite his public figure status, however, Nixon was held to have a legitimate expectation of privacy in his personal communications. Id.

21. The cases cited supra note 19 clearly indicate that it is only a voluntary action taken by the person with the privacy interest that can cause the loss of his expectation of privacy.

22. The privacy concerns in the voir dire context are identical to those in cases that have recognized the right's existence. The prospective juror finds herself in the same position which gave rise to the court's concern in Nixon and Whalen: questioned in an open courtroom in the presence of others front the community, a prospective juror may be placed in a position where a truthful response to the question posed will result in the unwanted disclosure of personal information that nay be enbarrassing and damaging. 
probing personal questions are minimized by protecting prospective jurors' privacy, the general reluctance of citizens to serve as jurors inay be reduced and the task of compiling a competent and conscientious jury may be easier. ${ }^{23}$ Therefore, because persons do not lose their reasonable expectations of privacy upon becoming prospective jurors and because there are good reasons for not making an exception to the constitutional protection normally accorded those expectations, prospective jurors should be recognized as having a constitutional right to privacy protecting them from disclosure of personal information during voir dire.

It is important to recognize, however, that this right is not to be applied "in the abstract." 24 As noted by each court recognizing the right's existence, it may be overridden by a more significant public imterest in having the information disclosed. ${ }^{25}$ Part II examines the countervailing interest in voir dire questioning.

II

\section{The Parties' Countervailing INTERest IN AN IMPARTIAL JURY}

Voir dire has been used for a number of purposes, the most basic of which are to establish a basis for challenges for cause ${ }^{26}$ and to facilitate the intelligent use of peremptory challenges ${ }^{27}$ in order to select an

23. Reluctance to serve as a juror is largely the result of the inconvenience that it entailse.g., potentially extensive time commitment, money lost because of time away froin work. Even if providing privacy protection does not actually reduce a citizen's general reluctance to serve, it certainly does not aggravate the problem, which would be the likely result if such protection were denied.

24. 433 U.S. at 458.

25. See, e.g., id.

26. Challenges for cause are decided by the court "on the ground of provable and legally cognizable evidence of partiality." Note, Selection of Jurors by Voir Dire Examination and Challenge, 58 YALE L.J. 638, 638 (1949). Such challenges nuay be based on either "imphed biaspartiality presumed by law froin the existence of certain relationships or interests of the jurors $\longrightarrow$ or on actual bias-a subjective state of mind that the court may consider prejudicial to a party's interests." Note, Voir Dire: Establishing Minimum Standards to Faeilitate the Exercise of Peremptory Challenges, 27 STAN. L. REv. 1493, 1499 n.29 (1975).

The situations that authorize a challenge of a prospective juror "for cause" are generally established by statute. In California, which has a statutory provision typical of many states, a prospective juror inay be challenged for cause (1) if the juror is related to a party to the hitigation; (2) if the juror has a unique interest in the subject matter; (3) if the juror has served in a related case or on the grand jury that indicted the accused; or most importantly (4) if the juror has a state of mind that will prevent her or him fronl acting with entire impartiality and without prejudice to the substantial rights of either party. Cal. Penal Code $\$ 1074$ (West Supp. 1981). See also CAL. Civ. Proc. Code $\$ 602$ (West Supp. 1981); Cal. Penal Code $\$ \$ 1071$, 1073 (West Supp. 1981).

27. The peremptory challenge is generally used "when an attorney suspects a prospective juror of being biased but cannot prove it to the judge according to the guidelines set down for challenges for cause." J. VAN DYKe, JURY Selection PRocedures 146 (1977). The suspicion may be based on real or imagined partiality. See Swain v. Alabaina, 380 U.S. 202, 220 (1965). 
-impartial jury ${ }^{28}$ as well as to project a sense of justice. ${ }^{29}$ But voir dire, particularly the use of peremptory challenges, has in many instances become a tool not for selecting an impartial jury but for assembling a jury that is more fair to one side than the other. ${ }^{30}$ Indeed, it has become axiomatic that "neither litigant is trying to choose 'impartial' jurors, but rather [is trying] to eliminate those who are sympathetic to the other side, hopefully leaving only those biased for him.,"31

In addition to manipulating the makeup of the jury, attorneys also frequently use voir dire for the purposes of indoctrinatimg the potential jurors on the merits of the case and developing rapport. Professor Saul Menlovitz, a member of the Chicago Jury Project, concluded froin his studies that attorneys spend over half of their time during voir dire preparing the jury for the case to be presented leaving less than half to be devoted to questions relatimg to possible bias or prejudice. ${ }^{32}$

Although voir dire is used for all these purposes, the only one

These challenges are "frequently exercised on grounds normally thought irrelevant to legal proceedings or official action, namely, the race, rehigion, nationality, occupation or affiliations of people summoned for jury duty." $I d$.

Another important function of the peremptory challenge is its use as a shield for the exercise of the challenges for cause. Questioning designed to elicit a basis for a challenge for cause may so alienate a potential juror that, although the lawyer failed to establish a basis for removal for cause, the ahenatmg process makes it necessary to exercise a peremptory challenge. See Babcock, supra note 1, at 554-55. See also Swain v. Alabama, 380 U.S. 202, $219-20$ (1965).

28. See Craig, Erickson, Friesen \& Maxwell, supra note 3, at 474.

29. As noted by one author:

[T] he peremptory challenge teaches the litigant, and through him the community, that the jury is a good and proper mode for deciding matters and that its decision should be followed because in a real sense the jury belongs to the litigant: he chooses it. Without giving any reason or meeting any legal test, lie may dismiss from "his" jury those he fears or hates the most, so that he is left with a good opinion of the jury. . . . The ideal that the pereinptory serves is that the jury not only should be fair and impartial, but should seein to be so to those whose fortunes are at issue.

Babcock, supra note 1, at 552.

30. Dunne, Mr. Dooley on Criminal Trials, in THE Judiclal Humorist 126 (W. Prosser ed. 1952). As noted by one author: "Bias will imevitably be found in trial juries; the question is whether that bias will be randomly present or selected by counsel." Okun, Investigation of Jurors By Counsel: Its Impact on the Decisional Process, 56 GEo. L.J. 839, 867 (1968).

31. Babcock, supra note 1, at 551. Babcock went on to note that "the interplay of the efforts of both sides to accomplish the same end should leave surviving jurors who are . . . "indifferent as they stand unsworn." "Id.

Prof. Okun addresses this claim as follows:

Some observers have been comforted by the thought that these goals [i.e. obtaining a "partial" jury] are beyond reach, that whcre individual advantage is sought by one attorney it is frustrated by the ability of his opponent to either challenge a panelist or secure one with an opposite bias. Unfortimately, a candid appraisal of the differences in litigant's resources deters reliance on any law of "cancellation of advantage."

Okun, supra note 30 , at 843.

32. H. Zeisel, H. Kalven, JR., \& B. Buchholz, Delay in Court 103 n.9 (2d ed. 1978). Indeed, one researcher concluded, after a series of studies, that the voir dire is more effectively used as a forum for indoctrination than as a means for screening out biased jurors. Broeder, Voir Dire Examinations: An Empirical Study, 38 S. CAL. L. REv. 503, 538 (1965). 
sanctioned by the courts is that of obtaining an impartial jury. ${ }^{33}$ It is only if the interest in an impartial jury is sufficiently infringed that a new trial will be granted for failure to permit a voir dire question to be asked. ${ }^{34}$ As the First Circuit stated in Schlinsky v. United States, "the purpose of the voir dire is to ascertain disqualifications, not to afford individual analysis in depth to permit a party to choose a jury that fits into some mold that he believes appropriate for his case." 35 Thus the only countervailing interest in voir dire questioning that may override the prospective jurors' privacy interests is the parties' interest in having an impartial jury.

The scope of this interest depends on the definition of "impartial jury." The right to an impartial jury is explicitly found in the sixth amendment ${ }^{36}$ and implicitly in the seventh amendment. ${ }^{37}$ It is further buttressed by the due process deinands of the fifth and fourteenth amendments. ${ }^{38}$ The language of the Constitution, however, offers no guidance as to what is meant by "impartiality." The courts liave therefore taken it upon themselves to define its meaning.

Judicial attempts to define the term "impartial" have concluded that it requires the jury to be coinposed of individuals with a "mental

33. Another legitimate purpose is that of obtaining jurors who are competent. CAL. Crv. Proc. CoDE \& 198(2) (West Supp. 1981). As a practical matter, however, questions implicating that interest are unlikely to implicate prospective jurors' privacy interests. The competency interest is therefore not dealt with in this Comment.

34. See, e.g., Rosales-Lopez v. United States, 101 S. Ct. 1629 (1981) (plurality opinion); Aldridge v. United States, 283 U.S. 308 (1931); United States v. Barnes, 604 F.2d 121, 137-43 (2d Cir. 1979). In United States v. Robinson, the court stated:

When the matter sought to be explored on voir dire does not relate to one of these recognized classes, it is incumbent upon the proponent to lay a foundation for his question by showing that it is reasonably calculated to discover an actual and likely source of prejudice, rather than pursue a speculative will-o-the-wisp. . . . Absent such a showing, [there is] no prejudice to the rights of the accused.

475 F.2d 376, 381 (D.C. Cir. 1973).

35. 379 F.2d 735, 738 (Ist Cir.), cert. denied, 389 U.S. 920 (1967).

36. The sixth amendment governs the defendant's rights in criminal proceedings: "In all criminal prosecutions, the accused shall enjoy the right to a speedy and public trial, by an impartial jury of the State . . . ." U.S. ConsT. amend. VI (enuphasis added). This sixth amendment provision was held to apply to the states in Duncan v. Louisiana, 391 U.S. 145, 149 (1968).

37. The seventh amendment governs civil proceedings: "In suits at common law, where the value in controversy shall exceed twenty dollars, the right of trial by jury shall be preserved . . . ." U.S. CoNST. amend. VII. Although the seventh amendment fails to nention the requirement that the jury in a civil proceeding be "impartial," such an understanding is implicit in the concept of jury trials and draws support from the due process requirements of the fifth and fourteenth amendment. See Hamer v. United States, 259 F.2d 274, 279 (9th Cir. 1958).

38. Wagner v. United States, 264 F.2d 524, 528 (9th Cir. 1959). The court in Hamer v. United States, 259 F.2d 274, 279 (9th Cir. 1958) noted: "Provided that the selection of the jury when viewed as a whole is fair and impartial, such a test would conport with the Supreme Court's view of the basic premise of the due process clauses of the fifth and fourteenth amendments of the Constitution." See also Ristaino v. Ross, 424 U.S. 589, 595 n.6 (1976); Irvin v. Dowd, 366 U.S. 717, 722 (1961); United States v. Barnes, 604 F.2d 121, 169 (2d Cir. 1979) (Meskill, J., dissenting). 
attitude of appropriate indifference," 39 who can decide the case solely on the evidence before them. ${ }^{40}$ Therefore, although the jurors inust be open to the evidence, they need not be totally ignorant of the facts and issues involved in a case. Given the modern day nethods of communication, a case of any importance can be expected to stimulate the interest of the public, and therefore virtually no informed citizen will be entirely free of impressions or opimions on the issues presented in the case. The courts have voiced their appreciation for this problein: "To hold that the inere existence of any preconceived notion as to the guilt or innocence of an accused, without more, is sufficient to rebut the presumption of a prospective juror's impartiality would be to establish an impossible standard. It is sufficient if the juror can lay aside his impression or opimion and render a verdict based on the evidence presented in court."41 If a tabula rasa were required, all informed citizens would be excluded from jury duty. ${ }^{42}$

The parties' interest in having an impartial jury can thus be defined as an interest in having a jury coinposed of persons who can objectively evaluate the evidence before them, even though they nay be

39. United States v. Wood, 299 U.S. 123, 145-46 (1936); see also Irwin v. Dowd, 366 U.S. 717,722 (1961).

40. Swain v. Alabaina, 380 U.S. 202, 219 (1965). The difficulty in supplying a nore precise definition was discussed in United States $v$. Wood: 'Impartiality is not a technical conception. It is a state of mind. For the ascertainment of this neental attitude of appropriate indifference, the Constitution lays down no particular tests and procedure is not chained to any ancient and artificial formula." 299 U.S. 123, 145-46 (1936).

41. Irwin v. Dowd, 366 U.S. 717, 723 (1961); see also Holt v. Unitcd States, 218 U.S. 245 (1910); Spies v. Illinois, 123 U.S. 131 (1887); Reynolds v. United States, 98 U.S. 145 (1878). The United States Suprcne Court reaffirmed its position in the recent case of Murphy v. Florida, 421 U.S. 794 (1975). Justice Thurgood Marshall's opinion for the nrajority stated that "[q]ualified jurors need not . . . be totally ignorant of the facts and issues involved," and that the governing standard was whether the prospective juror exhibited "a partiality that could not be laid aside." Id. at 799-800. See also Levit, Nelson, Ball \& Chernick, Expediting Voir Dire: An Empirical Study, 44 S. CAL. L. Rev. 916, 925 (1971).

42. Just the opposite is desirable. Jurors should be aware of the issues and should be prepared to bring life experiences to bear on the final outconre. As noted by Chief Justice John Marshall in the trial of Aaron Burr:

It would seem to the court that to say that any man who had formed an opinion on any fact conducive to the final decision of the case would therefore be considered as disqualified from serving on the jury, would exclude intelligent and observing nen, whose minds were really in a situation to decide upon the whole case according to the testimony, and would perhaps be applying the letter of the rule requiring an impartial jury with a strictness which is not necessary for the preservation of the rule itself.

United States v. Burr, 25 F. Cas. 49, 51 (D. Va. 1807) (No. 14,692g). In a more recent context, the opinion of Chief Justice Marshall was mirrored by Judge John Sirica. Judge Sirica asked a panel of prospective jurors, assentbled following the first Watergate indictments in January 1973, whether they had heard of the case. A number of prospective jurors indicated, in response, that they had not heard of Watergate. Justice Sirica was astonished, and suggested that those persons were perhaps the least qualified to sit on the jury, although they were also the ones least likely to have formulated opinions. J. VAN DYKe, supra note 27, at 143-44. 
somewhat familiar with certain aspects of the case. ${ }^{43}$ Under this definition, a voir dire question implicates the parties' right to an impartial jury if it is aimed at eliciting information that may be needed to determine the existence of a bias that would prevent a prospective juror from rendering a verdict based on the evidence presented im court. If a question is so aimed, the proponent of the question has a constitutionally recognized interest in having it asked that may conflict with prospective jurors' privacy interests. ${ }^{44}$

\section{III \\ RESOLVING THE CONFLICT IN INTERESTS}

The resolution of a conflict betwecn the prospective jurors' right to privacy and the parties' right to an impartial jury requires the saine delicate balancimg of interests commouly found in constitutional adjudication. Since the strength of the interests may vary considcrably dcpending on the type of information sought and the manner in which it is elicited, the balancing must be done on a qucstion by question basis. Furthermore, simce a prospective juror's privacy interest may be infringed as much by failing to answer a question as by answermg it, ${ }^{45}$ any necessary balancing must be performcd by the judge prior to the time the questions arc actually posed to the prospective jurors. ${ }^{46}$

In deciding whether a question slould be excluded for privacy reasons, the judge must first detcrmine whethcr a privacy interest cxists in not having the question asked. As discussed above, the presence of a privacy interest depends on the existence of a reasonable cxpectation of

43. Besides using voir dire, the parties' interest in impartiality can also be served through proper selection of the venire (i.e, cross section of the community), challenges to the array, change of venue, jury sequestration, continuances, and control of prejudicial news. See Note, Voir Dire: Establishing Minimum Standards to Facilitate the Exercise of Peremptory Challenges, 27 STAN. L. Rev. 1493, 1498 n.28 (1975).

44. Froin a strategic standpoint, the attorneys do not want to alienate the jurors and therefore may naturally shy away from embarrassing and sensitive questions. Additionally, attorneys are sensitive to the fact that most judges are hostile to prolonged examination, and there is generally an effort made to avoid boring or irritating the venire persous. Moreover, by the time of voir dire, the attorneys have in most instances conducted a pretrial investigation, or obtained a jury book from a private agency, which gives them sufficient infornation about the prospective jurors to exercise their peremptory challenges intelligently.

45. See, for example, the hypothetical at the beginning of this Comment.

46. In the typical case of voir dire examination in federal court, the judge solicits questions from counsel and makes a determination of which questions may properly be asked given the facts of the particular case. See FED. R. CIv. P. 47(a); FED. R. CRIM. P. 24(a). For the purpose of effectively protecting the privacy interest of prospective jurors, it is essential that this pre-questioning screening be imdertaken by the judge in all cases.

A situation may arise in which an attorney poses a question during voir dire which was never submitted to the judge for screening. This may be the case where a prospective juor responds to a question with an answer deserving of follow-up questioning. In such a situation, the judge will be forced to rule on the propriety of asking such a question immediately. 
privacy. ${ }^{47}$ While a person does not lose his reasonable expectation of privacy by becoming a prospective juror ${ }^{48}$ he will only have a privacy interest in not having a question asked if he has a reasonable expectation of privacy with respect to the specific information sought by that particular question.

The reasonable expectation of privacy test adopted in Nixon was taken from Katz $v$. United States..$^{49}$ There, Justice Harlan formulated a two-part test for determining when a reasonable cxpectation of privacy exists: First, "a person [inust] have exhibited an actual (subjective) expectation of privacy and, second, . . . this expectation [inust] be one that society is prepared to recognize as 'reasonable." "50 The subjective half of the Katz test is not particularly helpful here since the necessity of screening the questions before they are asked means that the determination of the existence of a privacy interest nnust be made without the benefit of investigating whether imdividual prospective jurors have exhibited an actual expectation of privacy as to the information sought by the question. Thus, the determination of the existence of a reasonable expectation of privacy must depend on whether society would recognize as reasonable a prospective juror's expectation of privacy in that information. To ineet this requireinent, the information must be such that society would recognize it as private, personal in nature, and potentially einbarrassing or harmful to a person's reputation if disclosed. $^{51}$ If the information sought does ineet this requirement, then the question, of course, should not be excluded on right to privacy grounds.

47. See supra text accompanying notes 15-18.

48. See supra text accompanying notes 19-22.

49. 389 U.S. 347 (1967): For the facts in Katz, see supra note 19.

Although the Nixon opinion cited the majority opinion in Katz, 433 U.S. at 458 , the reasonable expectation of privacy test comes from Justice Harlan's concurring opinion. 389 U.S. at 36061 (Harlan, J., concurring).

50. 389 U.S. at 361 (Harlan, J., concurring). The "reasonable expectation" standard compels courts to decide the degree of social solidarity or significance to raise a constitutional claim. See Note, supra note 19 , at $1473-74$.

51. See Whalen, 429 U.S. at 605 . Under this analysis, the judge would look to see if a substantial or significant part of society harbors strong personal feelings about a particular issue. If so, the judge may conclude that a question directed at that issue during voir dire is likely to violate a prospective juror's reasonable expectation of privacy. Such a review does not require that the judge compile outside information or conduct a poll. It only requires that the judge evaluate whether a significant portion of society wonld have a strong reaction to laving such a question asked. If the question concerns an issue that is controversial and rcasonable people are likely to be offended, embarrassed, or damaged by the asking of sucl a question on voir dire, the judge can safely determine that a prospective juror's expectation of privacy as to that issue is "rcasonable." This same kind of analysis of what is "reasonable" has been used by the Supreme Court in obscenity cases where the test is to look to "contemporary community standards." See Jenkins v. Georgia, 418 U.S. 153, 157 (1974); Hamling v. United States, 418 U.S. 87, 103-10 (1974); Miller v. California, 413 U.S. 15, 24 (1973). 
On the other hand, if a reasonable expectation of privacy does exist with respect to the specific information being sought, the question should be excluded unless it serves the parties' interest in having an impartial jury. Determining the existence of an impartial jury interest in having the question asked also requires focusing on the nature of the information sought by the question. As shown in Part II, a question does not imphicate the parties' interest in an impartial jury if the inforination sought is not relevant to determining the existence of a bias that would prevent a juror froin deciding the case according to the evidence presented at trial. ${ }^{52} \mathrm{~A}$ question inay also not involve an impartial jury interest if the parties already have the information that the question seeks. ${ }^{53}$

If a qucstion implicates both the prospective jurors' right to privacy and the parties' right to an impartial jury, a conflict between the two inay still be avoided by requiring the use of a less intrusive ineans to obtain the information. The use of less intrusive ineans serves to minimize any potential injury to the prospective jurors' privacy interests while at the same time allowing the information to be ehicited. This "least intrusive ineans" coinponent is impliedly required by the analysis of the privacy right in Nixon, where the Court went to great lengths to point out that the Act was the least intrusive means of ineeting the significant public interest in disclosure. ${ }^{54}$ Similarly, in the earher Whalen decision, the Court made a point of mentioning that the New York statute contained safeguards to prevent unwarranted disclosures and was, im its application, sensitive to the need to protect the privacy imterest of the individual. ${ }^{55}$ Thus, if less intrusive alteruatives exist for obtaining the information sought, the question should not be permitted.

There are many alternative means for obtaining information in the context of voir dire that may be less intrusive. One alternative is rephrasing questions in the least offensive way that is still likely to elicit the necessary information. Another possibility would be to use questionnaires to pose the personal questions, thereby avoiding the damage or embarrassment potentially associated with open court announcements. ${ }^{56}$ Whether the individual will be as candid im answering a questionnaire is difficult to say, but if the prospective juror is confident that

52. See supra text accompanying notes $39-43$.

53. Cf. Rosales-Lopez v. Umited States, 101 S. Ct. 1629, 1636 (1981) (plurality opinion) (defendant's impartial jury interest in having a question asked was lessened because he obtained substantially the same information from a different question).

54. 433 U.S. at $459-65$.

55. 429 U.S. at 605.

56. Comment, Voir Dire in California Criminal Trials: Where is it Going? Where Should it Go?, 10 SaN Diego L. Rev. 395, 407 (1973). 
the information will only be available to the attorneys and the judge, full disclosure can be expected. Yet another alternative is to have the judge ask in camera those questions found to violate privacy interests.

If no less intrusive means exist or if a conflict exists despite their use, the judge must then balance the two constitutionally protected interests to determine whether the question should be asked. Although the balancing of two such significant rights is a difficult task, several factors exist that provide guidance.

The prospective jurors' privacy interest will be greater the more private and sensitive the information. In addition, the degree of publication that is likely to result from the information being disclosed and the nature of the publication audience should be considered. If, for example, less intrusive means are used, both the extent of publication and the nature of the audience nay be sufficiently limited to make the probable degree of privacy damage very small. On the other hand, the sinaller the community, the more likely it is that there will be someone present at the venire who knows the prospective juror and will commumicate the information to others who work and socialize with her, thus increasing the likelihood that the revelation will be damaging.

As for the parties' interest in an impartial jury, the inore likely it is that the information sought will reveal a damaging bias, the greater the interest in asking a particular question. For example, if significant publicity has been given to the case, there may be a greater likelihood that prospective jurors will have acquired a bias on the issues and thus a greater likelihood that a particular question would reveal a damaging bias. The interest in asking a question also increases as the inateriality of the bias to the ultimate decision in the case increases. ${ }^{57} \mathrm{~A}$ final factor that should be considered in weighing the impartiality interest is the maguntude of the claim or punishment at stake in the case. This factor would be paramount, for example, in a inurder trial where the result of bias in the jury may well be a conviction and lengthy prison sentencesoinetimes death. Since both parties have a great deal to lose-the defendant his freedom and the public the possibility of having a nurderer go free-there inay be very few relevant questions that should not be permitted even though they violate a prospective juror's privacy right. ${ }^{58}$

The application of the method described in this Part for resolving

57. Cf. United States v. Barnes, 604 F.2d 121, 140 (2d Cir. 1979) (stating that nuany cases uphold the trial court's decision to limit voir dire on the grounds that the natter sought to be probed was too renote fron the issues in the case to warrant the intrusion into potential jurors' private thoughts).

58. Cf. Aldridge v. United States, 283 U.S. 308, 314 (1931) (taking into account the severity of possible punishment on conviction in deciding that the strength of the defendant's impartiality interest justified granting a new trial as a result of the trial court's failure to permit a voir dire question on racial prejudice). 
a conflict between the prospective jurors' privacy interests and the parties' interest in having an impartial jury can be illustrated by applying it to the alderman example discussed at the beginning of this Comment. In that cxample, the suit alleges ten thousand dollars in damages as a result of overmedication by the psychiatric institution's staff and the defendant's attorney wants to ask prospective jurors whcther they have ever been patients at a psychiatric hospital. Upon the attorney's submission of his proposed voir dire questions, the judge must first determine whether prospective jurors have a reasonable expectation of privacy with respect to the information sought. Since the question in the example relates to information that may be both private and embarrassing, the judge would probably conclude that a reasonable expectation of privacy exists. However, assuming the information is not otherwise available, the defendant's conflicting interest in an impartial jury probably militates in favor of having the question asked since it may be relevant to the issues im the case. For example, the dcfendant's attorney may believe that former psychiatric patients are biased for or against psychiatric institutions or patients.

Faced with an apparent conflict of interests, the court should determine whether the same information could be obtained by less intrusive means, such as questioning in chambers. If the question is aimed at detecting a bias for or against psychiatric patients or hospitals, it could be rephrascd to inquire directly about sucl a bias and would be equally useful and less intrusive. Alternatively, other less intrusive means, such as questionnaires, could help minimize the conflict of interests.

Assuming lcss intrusive means could not be used, the court would then be forced to balance the conflicting interests. The prospective jurors' privacy interest is potcntially great. The fact that a person once received treatment at a psychiatric institution is information that is frequently very sensitive and private. Furthermore, since no less intrusive means are being used and the proceeding is taking place in a small community, disclosure could result in extensive publicity to a familiar audience, whicl could cause extensive injury to the prospective juror's privacy interests. On the other hand, while the biases and issues to which the information relates may be inportant, the relationship between being a former psychiatric patient and any bias for or against psychiatric patients or hospitals is tenuous, and the question thus inay be unlikcly to reveal a damaging bias. Furthermore, simce the clain is for only ten thousand dollars, the dcfendant's stake in the action is relatively mmor and does not justify extensive intrusions into prospective jurors' privacy. Thus, in the final balance a court may well conclude that the prospective juror's privacy interest should prevail, and the de- 
fendant's attorney should not be allowed to ask the question..$^{59}$

\section{CONCLUSION}

Our system of adversarial justice is predicated on willing, enthusiastic, and dedicated participation of citizens summoned to fulfill the role of juror. This conscientious involvement is, in theory, fostered by the citizens' behef in the workability of the system, as well as confidence in the ideal sought as the ultimate end of the process-justice. The process of voir dire, as presently practiced, undermines the basic confidence essential to the proper administration of justice. Rather then willingly fulfilling a pubhic service, the person called for jury service typically succumbs begrudgingly to the jury summons. This same citizen then becomes witness to a process whose chief purpose is all too frequently to compile as prejudiced a jury as possible, with each side skillfully using challenges to alter the jury persuasion in favor of its chent. In evading the constitutionally mandated requirement of selecting an impartial jury, the attorneys typically probe into the personal behefs and backgrounds of those assembled, often at the cost of privacy rights. The result of the experience is too often the disillusionment of the citizen, who is likely to feel he is contributing more to the abuse of process then the ultimate achievement of justice. ${ }^{60}$

This Comment does not propose a solution to all of the problems, yet it does offer some guidence into how efforts at achieving an impartial jury can be advanced while at the same time respecting the rights of the prospective juror. The harmonization of these two interests can

59. A potential problem area with the adoption of a more restricted voir dire based on this Comment's analysis is that the reduction in the amount of information that can be obtained during voir dire may result in increased pretrial investigation. In addition to the fact that the defendant generally has fewer resources available than the prosecution to conduct extensive pretrial investigation, there is also the problein that there are fewer controls over pretrial investigatory activities. Fewer controls may translate into even greater abuses of the privacy rights of prospective jurors. Therefore, in order for the limitations on voir dire to be effective, judges must be sensitive to what goes on in pretrial investigations. Such sensitivity inay manifest itself, for example, in a refusal by the judge to release the names of the prospective jurors until shortly before trial.

60. Compare this with de Tocqueville's early impressions of the U.S. jury system:

The jury is, above all, a pohtical institution, and it must be regarded in this light in order to be duly appreciated. . . . The institution of the jury . . . invests the people . . . with the direction of society. . . . . It imbues all classes with a respect for the thing judged and with the notion of right. . . . It makes them all feel the duties which they are bound to discharge towards society, and the part which they take in its government.

A. De Toceueville, Democracy in America 127-28 (New American Library ed. 1956). 
only strengthen the public view of the justice system and increase the willingness of individuals to participate in it.

Michael R. Glover*

* B.A. 1979, Stanford University; third-year student, Boalt Hall School of Law, University of California, Berkeley. 